\title{
Anti-obesity Effects of Juniperus chinensis Extract Are Associated with Increased AMP-Activated Protein Kinase Expression and Phosphorylation in the Visceral Adipose Tissue of Rats
}

\author{
Seung-Jin KIM, ${ }^{a}$ Jin Young JUNG, ${ }^{a}$ Ha Won KIM, ${ }^{b}$ and Taesun PARK ${ }^{*, a}$ \\ ${ }^{a}$ Department of Food and Nutrition, Brain Korea 21 Project, Yonsei University; 134 Shinchon-dong, Sudaemun-ku, Seoul \\ 120-749, Korea: and ${ }^{b}$ Department of Life Sciences, University of Seoul; 90 Jeonnong-dong, Dongdaemun-ku, Seoul \\ 130-743, Korea. $\quad$ Received January 4, 2008; accepted April 18, 2008; published online April 22, 2008
}

This study evaluates the protective effect of Juniperus chinensis hot water extract (JCE) against high-fat-diet (HFD)-induced obesity and its molecular mechanisms in the visceral adipose tissue of rats. JCE supplementation significantly lowered body weight gain, visceral fat-pad weights, blood lipid levels, and blood insulin and leptin levels of rats rendered obese by an HFD. Feeding with JCE significantly reversed the HFD-induced down-regulation of the epididymal adipose tissue genes implicated in adipogenesis, such as the peroxisome proliferator-activated receptors $\gamma 2(\mathrm{PPAR} \gamma 2)$, adipocyte protein 2 (aP2), sterol regulatory element binding protein 1c (SREBP1c), fatty acid synthase (FAS), and HMG-CoA reductase (HMGR), as well as those involved in uncoupled respiration, such as the uncoupling protein 2 (UCP2) and uncoupling protein 3 (UCP3). Dietary supplementation with JCE also reversed the HFD-induced decreases in the AMP-activated protein kinase (AMPK) and the acetyl-CoA carboxylase 2 (ACC2) expressions at both the mRNA and protein levels and restored the HFD-induced inhibitions in the AMPK and ACC2 phosphorylation, which are related to fatty acid $\beta$-oxidation, in the epididymal adipose tissue. This study reports, for the first time, that the JCE can have an anti-obesity effect in a rodent model with HFD-induced obesity through an enhanced gene transcription of the uncoupling protein as well as an elevated AMPK protein expression and phosphorylation in the visceral adipose tissue.

Key words Juniperus chinensis; high-fat diet; anti-obesity effect; AMP-activated protein kinase; uncoupling protein; epididymal adipose tissue

Obesity and associated disorders, occurrences of which have increased significantly worldwide in the last decades, pose serious risks to the present and future health of mankind. The World Health Organization estimates that more than one billion adults worldwide are overweight and 300 million are clinically obese based on a body mass index (BMI) of $30 \mathrm{~kg} / \mathrm{m}^{2}$ or higher. ${ }^{1)}$ Obesity alone can induce all symptoms of metabolic syndrome, which is associated with many additional health problems, including increased risk of insulin resistance, non-alcoholic fatty liver, atherosclerosis, degenerative disorders such as dementia, some immunemediated disorders such as asthma, and certain cancers. ${ }^{2,3)}$ Rodents fed a lard-based high-fat-diet (HFD) showed visceral adiposity, hyperglycemia, dyslipidemia, hyperinsulinemia, and hepatic steatosis, which are distinctly linked with human obesity. Increased free fatty acid or saturated fatty acid incursion from an HFD not only produces adipogenesis but also leads to the metabolic disease and chronic activation of inflammatory responses in rodents and humans. ${ }^{4,5}$

Adipogenesis, a process in which a multipotent mesenchymal stem cell is differentiated into a mature adipocyte, includes an extremely controlled and organized cascade of transcription factors, such as members of the peroxisome proliferator-activated receptors (PPARs), the CCAAT/enhancer binding proteins $(\mathrm{C} / \mathrm{EBPs})$, and the sterol regulatory element binding protein (SREBP) family. ${ }^{6}$ ) Differentiated adipocytes store fatty acids in the form of triglycerides in their cytoplasm, with the involvement of various enzymes such as strearoyl-CoA desaturase-1 and fatty acid synthase $(\mathrm{FAS}){ }^{7)}$ AMP-activated protein kinase (AMPK) stimulates the pathways that increase energy production such as glucose transport and fatty acid oxidation, and switches off the pathways that consume energy such as lipogenesis, protein synthesis, and gluconeogenesis. ${ }^{8)}$ The uncoupling proteins (UCPs), present in the mitochondrial inner membrane, mediate a controlled discharge of the proton gradient that is produced by the respiratory chain. Through this energy-dissipatory mechanism, UCPs are associated with thermogenesis and the maintenance of redox balance in the adipose tissue, ${ }^{9)}$ and are also regarded as new molecular targets to understand adipocyte metabolism. ${ }^{10)}$

Herbal weight-loss supplements are being marketed worldwide lately with claims of efficacy. Some of these supplements, including Ephedra sinica, Paullinia cupana, Plantago psyllium, and Pausinystalia yohimbe, have harmful effects, whereas Garcinia cambogia and Ilex paraguariensis are considered relatively safe and merit further investigation. ${ }^{11)} \mathrm{Ju}$ niperus chinensis is an ornamental tree with scaly, partly needle, and year-round foliages, that grows in the East Asian region. ${ }^{12)}$ The antioxidant-active compounds, such as quercetin, naringenin, taxifolin, aromadendrin, and isoquercitrin, have been isolated from the heartwood of this plant. ${ }^{13)}$ The compounds possessing potential therapeutic or biological effects found in Juniperus chinensis include flavones, lignans, and natural oils including diterpenes and norditerpenes. ${ }^{14,15}$ ) The leaves of $J$. chinensis contains podophyllotoxin, a lignan with strong anti-leukemic and antitumor activities, ${ }^{16,17)}$ and sesquiterpene, a terpene with antifungal activity. ${ }^{18)}$ The dried heartwood of this tree has been used as a traditional folk medicine for the remedies of cold, urinary infection, urticaria, dysentery, hemorrhage, and rheumatic arthritis. ${ }^{19)}$ Its stems have been used to treat parasitic skin problems and rheumatism, whereas its berries are traditionally used in East Asia to treat convulsions, excessive sweating, and hepatitis. ${ }^{20)}$ The biological functions of $J$. chinensis in weight-reduction and its regulation of obesity- 
related metabolic diseases have not yet been studied. Therefore, this study evaluates the anti-obesity activity of a hot water extract of $J$. chinensis heartwood in a rat model with HFD-induced obesity and elucidates molecular mechanisms behind such an effect as exerted in the visceral adipose tissue.

\section{MATERIALS AND METHODS}

Preparation of $\boldsymbol{J}$. chinensis Water Extract The small pieces of heartwood of $J$. chinensis $(5 \mathrm{~kg})$, which is commonly known as 'Zadanhyang' in Korea, was mixed with water (301) and subjected to continuous hot extraction $\left(90^{\circ} \mathrm{C}, 5 \mathrm{~h}\right)$. The resulting water extract was filtered and then lyophilized to yield $155.7 \mathrm{~g}$ (3.1\% of the initial amount) of powder. The concentration used in the experiment was based on the dry weight of the extract.

Animals and Experimental Diets Twenty-four 5-weekold male Sprague-Dawley rats (Orient, Gyeonggi-do, Korea) were housed in a temperature- $\left(21 \pm 2.0^{\circ} \mathrm{C}\right)$ and humidity$(50 \pm 5 \%)$ controlled room with a ratio of 12 -h light/12-h darkness, and were fed a commercial diet (Ralston-Purina, St. Louis, MO, U.S.A.) for 1 week. The twenty-four rats were randomly divided into three groups $(n=8)$ and fed a normaldiet (ND), an HFD, or the $J$. chinensis extract-supplemented diet (HFD+JCE) for $79 \mathrm{~d}$. The HFD contained $200 \mathrm{~g}$ fat $/ \mathrm{kg}$ ( $170 \mathrm{~g}$ lard plus $30 \mathrm{~g}$ corn oil) and $1 \%$ cholesterol $(\mathrm{w} / \mathrm{w})$. It was formulated to provide $40 \%$ of the total energy generated by the diet from fat by replacing carbohydrate energy with lard and corn oil, and had the same amount of vitamins and minerals per $\mathrm{kJ}$ as the ND did. The HFD+JCE was identical to the HFD and contained 1\% JCE (Table 1). The diets were given in the form of pellets. The rats' food intakes were recorded daily, and their body weights were monitored every $3 \mathrm{~d}$.

At the end of the feeding period, the rats were anesthetized with diethyl ether after an overnight fast. Blood was drawn from the abdominal aorta into a vacuum tube and their epididymal fat pads were removed, weighed, and frozen with liquid nitrogen. This study adhered to the Guide for the Care and Use of Laboratory Animals developed by the Institute of Laboratory Animal Resources of the National Research Council, and was approved by the Institutional Animal Care and Use Committee of Yonsei University in Seoul, Korea.

Biochemical Analyses Plasma concentrations of total cholesterol, HDL cholesterol, free fatty acid, and triglyceride were determined enzymatically using commercial kits (BioClinical System, Gyeonggi-do, Korea). Plasma LDL+VLDL cholesterol concentrations were calculated by subtracting the HDL cholesterol concentration from the total cholesterol concentration.

Plasma insulin and leptin levels were measured through radioimmunoassay using commercially available kits (Linco Research, Charles, MO, U.S.A.). The assay utilized ${ }^{125} \mathrm{I}-\mathrm{la}-$ belled rat insulin and guinea pig anti-rat insulin serum to determine the total (free of and bound to plasma proteins) insulin level in the plasma. The plasma insulin concentration was counted in a gamma counter (Packard COBRA 5010 Quantum, GMI, Packard Instrument, Meriden, CT, U.S.A.) for $1 \mathrm{~min}$, and was calculated in $\mathrm{ng} / \mathrm{ml}$. The plasma leptin concentration was determined through the same procedure
Table 1. Composition of Experimental Diets

\begin{tabular}{|c|c|c|c|}
\hline Ingredients & ND & HFD & $\mathrm{HFD}+\mathrm{JCE}$ \\
\hline & $\mathrm{g} / \mathrm{kg}$ diet & & \\
\hline Casein & 200 & 200 & 200 \\
\hline DL-Methionine & 3 & 3 & 3 \\
\hline Corn starch & 150 & 111 & 101 \\
\hline Sucrose & 500 & 370 & 370 \\
\hline Cellulose & 50 & 50 & 50 \\
\hline Corn oil & 50 & 30 & 30 \\
\hline Lard & - & 170 & 170 \\
\hline Vitamin $\operatorname{mix}^{a)}$ & 10 & 12 & 12 \\
\hline Mineral mix ${ }^{b)}$ & 35 & 42 & 42 \\
\hline Choline bitartrate & 2 & 2 & 2 \\
\hline Cholesterol & - & 10 & 10 \\
\hline tert-Butylhydroquinone ${ }^{c)}$ & 0.01 & 0.04 & 0.04 \\
\hline J. chinensis hot-water extract & - & - & 10 \\
\hline Total $(g)$ & 1000 & 1000 & 1000 \\
\hline Fat $(\%$ calorie $)$ & 11.5 & 39.0 & 39.0 \\
\hline Total energy, $\mathrm{kJ} / \mathrm{kg}$ diet & 16439 & 19315 & 19315 \\
\hline
\end{tabular}

ND, normal diet; HFD, high-fat diet; HFD+JCE, HFD plus 1\% JCE supplemented diet. a) AIN-76 Vitamin mixture ( $\mathrm{g} / \mathrm{kg}$ mix); thiamin $\cdot \mathrm{HCl} 0.6$; riboflavin 0.6 ; nicotinamide 25 ; pyridoxine $\cdot \mathrm{HCl} 0.7$; nicotinic acid 3; D-calcium pantothenate 1.6 ; folic acid 0.2 ; D-biotin 0.02 ; cyanocobalamin (Vitamin $\mathrm{B}_{12}$ ) 0.001 ; retinyl palmitate $(250000 \mathrm{IU} / \mathrm{gm}) 1.6$; DL- $\alpha$-tocopherol acetate $(250 \mathrm{IU} / \mathrm{gm}) 20$; cholecalciferol (Vitamin $\mathrm{D}_{3}$ ) 0.25 ; menaquinone (Vitamin $\mathrm{K}_{2}$ ) 0.05; sucrose, finely powdered 972.9. b) AIN76 mineral mixture (g/kg of mix); $\mathrm{CaHPO}_{4} 500 ; \mathrm{NaCl} 74 ; \mathrm{K}_{2} \mathrm{H}_{6} \mathrm{O}_{7} \mathrm{H}_{2} \mathrm{O} 220 ; \mathrm{K}_{2} \mathrm{SO}_{4} 52$; $\mathrm{MgO} 24 ; \mathrm{MnCO}_{3} 3.57 ; \mathrm{Fe}\left(\mathrm{C}_{6} \mathrm{H}_{5} \mathrm{O}_{7}\right) \cdot 6 \mathrm{H}_{2} \mathrm{O}$ 6; $\mathrm{ZnCO}_{3} 1.6 ; \mathrm{CuCO}_{3} 0.3 ; \mathrm{KIO}_{3} 0.01$; $\mathrm{Na}_{2} \mathrm{SeO}_{3} \cdot 5 \mathrm{H}_{2} \mathrm{O} 0.01$; CrK $\left(\mathrm{SO}_{4}\right)_{2} 0.55$; sucrose, finely powdered 118 . c) Antioxidant agent, $0.01 \mathrm{~g} / 50 \mathrm{~g}$ lipids.

used for the insulin measurement. The lower limits of sensitivity for the insulin and leptin assays were $15 \mathrm{pmol} / \mathrm{l}$ and $0.5 \mu \mathrm{g} / 1$, respectively. The plasma glucose concentration was determined using an automatic analyzer (Express Plus, Chiron Diagnostics, East Walpole, MA, U.S.A.) with reagents (BioClinical System, Gyeonggi-do, Korea).

RNA Isolation and RT-PCR Analysis The total RNA was isolated from the epididymal fat tissue of each rat using Trizol (Invitrogen, Carlshad, CA, U.S.A.) and pooled for RTPCR analysis for each group $(n=8)$. Four micrograms of the total RNA was reverse-transcribed using the Superscript II kit (Invitrogen, Carlshad, CA, U.S.A.), according to the manufacturer's recommendations. The primers for the PCR analysis were synthesized at Bioneer (Daejun, Korea). Using the primers listed in Table 2, the PCR analysis was performed with cDNA as a template. The glyceraldehyde-3phosphate dehydrogenase (GAPDH) gene was used as an internal control for semi-quantitative RT-PCR. The PCR was carried out as follows: $5 \mathrm{~min}$ at $94^{\circ} \mathrm{C}, 30$ cycles of $94^{\circ} \mathrm{C}$ for $30 \mathrm{~s}, 55$ or $60^{\circ} \mathrm{C}$ for $45 \mathrm{~s}$, and $72^{\circ} \mathrm{C}$ for $1 \mathrm{~min}$, and $10 \mathrm{~min}$ incubation at $72^{\circ} \mathrm{C}$.

Western Blot Analysis The epididymal fat pads were homogenized at $4{ }^{\circ} \mathrm{C}$ in an extraction buffer $(100 \mathrm{~mm}$ Tris- $\mathrm{HCl}$, pH 7.4, $5 \mathrm{~mm}$ EDTA, $50 \mathrm{~mm} \mathrm{NaCl}, 50 \mathrm{~mm}$ sodium pyrophosphate, $50 \mathrm{~mm} \mathrm{NaF}, 100 \mathrm{~mm}$ orthovanadate, $1 \%$ Triton $\mathrm{X}-100,1 \mathrm{~mm}$ phenylmethanesulphonylfluoride, $2 \mu \mathrm{g} / \mathrm{ml}$ aprotinin, $1 \mu \mathrm{g} / \mathrm{ml}$ pepstatin $\mathrm{A}$, and $1 \mu \mathrm{g} / \mathrm{ml}$ leupeptin). The tissue homogenates were centrifuged $(13000 \times \boldsymbol{g}, 20 \mathrm{~min}$, $4{ }^{\circ} \mathrm{C}$ ) and the resulting supernatants (whole-tissue extracts) were used for the Western blot analyses. The total protein concentrations of the whole tissue extracts were determined through Bradford assay (Bio-Rad, CA, U.S.A.).

The protein samples (100 $\mu \mathrm{g} / \mathrm{lane})$ were separated with $8 \%$ SDS-PAGE and were transferred onto the nitrocellulose 
Table 2. Primer Sequences and PCR Conditions

\begin{tabular}{|c|c|c|c|}
\hline Gene description & Primers & Sequences $\left(5^{\prime} \rightarrow 3^{\prime}\right)$ & Annealing temperature $\left({ }^{\circ} \mathrm{C}\right)$ \\
\hline \multirow{2}{*}{$\begin{array}{l}\text { Peroxisome proliferators activated receptor } \gamma 2 \\
\quad(\operatorname{PPAR} \gamma 2)\end{array}$} & $\mathrm{F}$ & TGGGTGAAACTCTGGGAGAT & 55 \\
\hline & $\mathrm{R}$ & CCATAGTGGAAGCCTGATGC & \\
\hline \multirow{2}{*}{$\begin{array}{l}\text { Sterol regulatory element binding protein-1c } \\
\text { (SREBP1c) }\end{array}$} & $\mathrm{F}$ & TTGTGGAGCTCAAAGACCTG & 55 \\
\hline & $\mathrm{R}$ & TTGTGGAGCTCAAAGACCTG & \\
\hline \multirow[t]{2}{*}{ CCAAT/enhancer binding protein $\alpha(\mathrm{C} / \mathrm{EBP} \alpha)$} & $\mathrm{F}$ & AAGGCCAAGAAGTCGGTGGA & 55 \\
\hline & $\mathrm{R}$ & CCATAGTGGAAGCCTGATGC & \\
\hline \multirow[t]{2}{*}{ Adipocyte protein $2(\mathrm{aP} 2)$} & $\mathrm{F}$ & AACACCGAGA TTTCCTTCAA & 55 \\
\hline & $\mathrm{R}$ & CACCACCAGC TTGTCACCA & \\
\hline \multirow[t]{2}{*}{ Fatty acid synthase (FAS) } & $\mathrm{F}$ & TGTTCTCAAGGAAGGCACTG & 55 \\
\hline & $\mathrm{R}$ & GAGTCCACCCACTGGAAACT & \\
\hline \multirow{2}{*}{ HMG-CoA reductase (HMGR) } & $\mathrm{F}$ & AAGAGTCGCTGTGTTCAC & 60 \\
\hline & $\mathrm{R}$ & CTGCTCCCACACTCTAAGTC & \\
\hline \multirow[t]{2}{*}{ Uncoupling protein 1 (UCP1) } & $\mathrm{F}$ & GGGACCTACAATGCTTACAG & 60 \\
\hline & $\mathrm{R}$ & GGTCATATGTCACCAGCTCT & \\
\hline \multirow[t]{2}{*}{ Uncoupling protein 2 (UCP2) } & $\mathrm{F}$ & CAAGCTTATGGTTGGTTTCAAGGCCACCGA & 60 \\
\hline & $\mathrm{R}$ & CAAGCTTCAAAAGGGTGCCTCCCGGGATTC & \\
\hline \multirow[t]{2}{*}{ Uncoupling protein 3 (UCP3) } & $\mathrm{F}$ & ACGGATGTGGTGAAGGTCCG & 60 \\
\hline & $\mathrm{R}$ & TACAAACATCATCACGTTCC & \\
\hline \multirow[t]{2}{*}{ AMP-activated protein kinase (AMPK) } & $\mathrm{F}$ & TCAGGCACCCTCATATAATC & 60 \\
\hline & $\mathrm{R}$ & TGACAATAGTCCACACCAGA & \\
\hline \multirow{2}{*}{ Acetyl-CoA carboxylase 2 (ACC2) } & $\mathrm{F}$ & GTCCTCATCATGAACGGCTG & 60 \\
\hline & $\mathrm{R}$ & AGGACAGTGGGGTCGTTTTC & \\
\hline \multirow{2}{*}{$\begin{array}{l}\text { Glyceraldehyde-3-phosphate dehydrogenase } \\
\text { (GAPDH) }\end{array}$} & $\mathrm{F}$ & AGAACATCATCCCTGCATCC & 60 \\
\hline & $\mathrm{R}$ & TCCACCACCCTGTTGCTGTA & \\
\hline
\end{tabular}

membrane (Amersham, Buckinghamshire, U.K.). After the membrane was incubated in $5 \%$ bovine serum albumin in Tris-buffered saline-Tween 20 for $2 \mathrm{~h}$, it was incubated overnight with the specific antibodies against acetyl-CoA carboxylase 2 (ACC2) (Santa Cruz Biotechnology, Inc., CA, U.S.A.); phospho-ACC at Ser 79 (Cell Signaling Technology, MA, U.S.A.); AMPK (Cell Signaling Technology, MA, U.S.A.); phospho-AMPK at Thr 172 (Cell Signaling Technology, MA, U.S.A.); $\alpha$-tubulin (Calbiochem, Darmstadt, Germany). After the membrane was again incubated with the relative second antibody, immunoreactive signals were detected using the chemiluminescent detection system (Amersham, Buckinghamshire, U.K.), and were quantified using the Quantity One analysis software (Bio-Rad, CA, U.S.A.).

Statistical Analysis All the results are expressed as the means \pm S.E.M. of 8 rats in each group. Statistical evaluation was done using one-way ANOVA, followed by Duncan's multiple range tests. The level of significance was set at $p<0.05$ for all the statistical tests.

\section{RESULTS}

Body Weight, Food Intake, and Visceral Fat-Fad Weight The final body weight and the body weight gain $(\mathrm{g} / 79 \mathrm{~d})$ of the rats in the HFD group were $44 \%$ and $85 \%$ greater $(p<0.05)$, respectively, than the values for the ND rats. Dietary supplementation of the HFD with JCE significantly reduced the final body weight (by $10 \%, p<0.05$ ) and the body weight gain (by $14 \%, p<0.05$ ) of the rats compared to those observed in the HFD rats (Table 3 ). The JCE did not affect the rats daily food intake but significantly lowered the food efficiency ratio (FER) of the rats on the HFD $(p<0.05)$ (Table 3). The HFD-induced increase in the relative weight of the total visceral fat-depots was reversed by feeding the rats with the JCE $(16 \%$ decrease, $p<0.05)$. The epididymal, perirenal, retroperitoneal, and mesenteric fat-pad weights of
Table 3. Body Weight and Food Intake of Rats Fed Experimental Diets

\begin{tabular}{lccc}
\hline \hline & ND & HFD & HFD $+\mathrm{J}$ \\
\hline Initial body weight $(\mathrm{g})$ & $169.2 \pm 1.2$ & $168.6 \pm 3.3$ & $169.1 \pm 3.3$ \\
Final body weight $(\mathrm{g})$ & $399.2 \pm 11.4^{\mathrm{c}}$ & $573.8 \pm 18.2^{\mathrm{a}}$ & $515.2 \pm 19.8^{\mathrm{b}}$ \\
Body weight gain & $230.0 \pm 10.9^{\mathrm{c}}$ & $426.6 \pm 17.2^{\mathrm{a}}$ & $366.6 \pm 16.5^{\mathrm{b}}$ \\
$\quad(\mathrm{g} / 79 \mathrm{~d})$ & & & \\
Food intake (g/d) & $21.30 \pm 0.36^{\mathrm{b}}$ & $24.02 \pm 0.44^{\mathrm{a}}$ & $24.09 \pm 0.63^{\mathrm{a}}$ \\
FER $^{a}$ & $0.16 \pm 0.006^{\mathrm{c}}$ & $0.25 \pm 0.009^{\mathrm{a}}$ & $0.21 \pm 0.008^{\mathrm{b}}$ \\
\hline
\end{tabular}

Values are mean \pm S.E.M., $n=8$. a,b,c Means not sharing a common superscript are significantly different $(p<0.05)$. ND, normal diet; HFD, high-fat diet; HFD+JCE, HFD plus $1 \%$ JCE supplemented diet. $a$ ) Food efficiency ratio (FER) $=($ body weight gain for experimental period $(\mathrm{g} / \mathrm{d})) /($ food intake for experimental period $(\mathrm{g} / \mathrm{d}))$.

the rats fed the HFD+JCE were reduced by $34 \%, 31 \%, 31 \%$, and $30 \%$, respectively, compared to the rats on the HFD $(p<0.05)$ (Fig. 1).

Blood Biochemistries The plasma total and LDL + VLDL cholesterol concentrations were $86 \%$ and $282 \%$ higher, respectively, in the HFD rats than in the ND rats $(p<0.05)$, whereas the plasma HDL cholesterol concentration was $55 \%$ lower in the HFD rats than in the ND rats $(p<0.05)$ (Table 4). As a result, the atherogenic index of the HFD rats was $1015 \%$ of the corresponding value for the ND rats $(p<0.05)$. The plasma triglyceride and free fatty acid concentrations also significantly increased (by $200 \%$, $p<0.05$ and $58 \%, p<0.05$, respectively) in the rats fed the HFD compared to the ND-fed rats $(p<0.05)$. The plasma glucose, insulin, and leptin levels of the rats administered the HFD were $34 \%, 55 \%$, and $120 \%$ higher, respectively, than those of the ND rats $(p<0.05)$ (Table 4$)$.

The HFD-induced dyslipidemia significantly improved after the dietary supplementation with the JCE. The plasma total cholesterol and LDL + VLDL cholesterol concentrations were $33 \%$ and $45 \%$ lower, respectively, in the rats fed the HFD + JCE than in the HFD-fed rats $(p<0.05)$, whereas the 


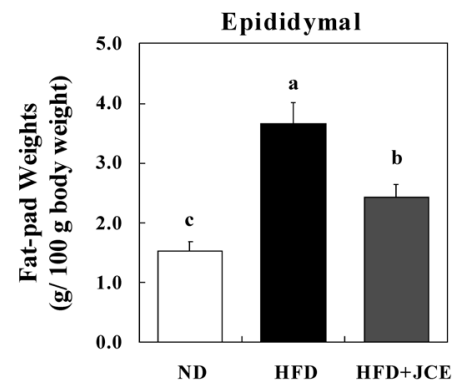

D

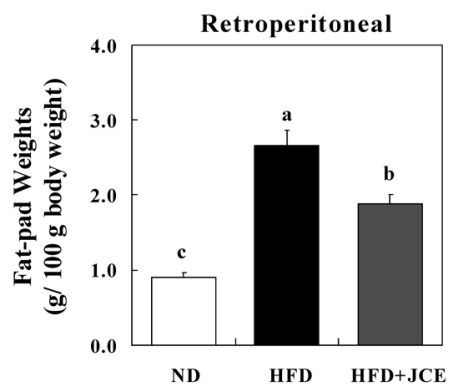

B

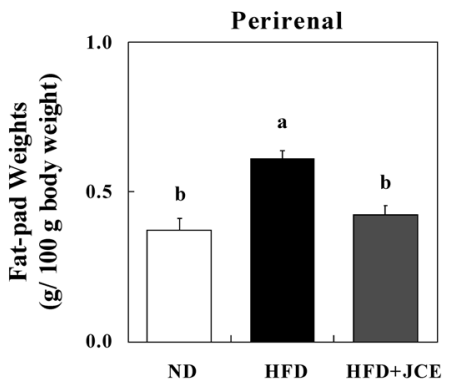

$\mathbf{E}$

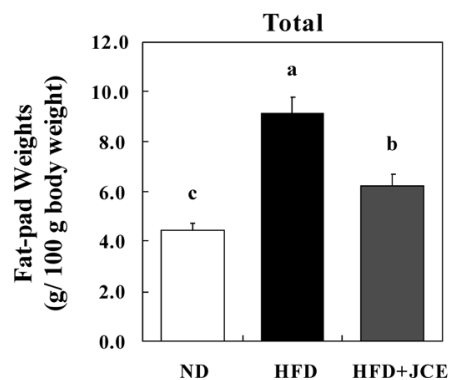

C

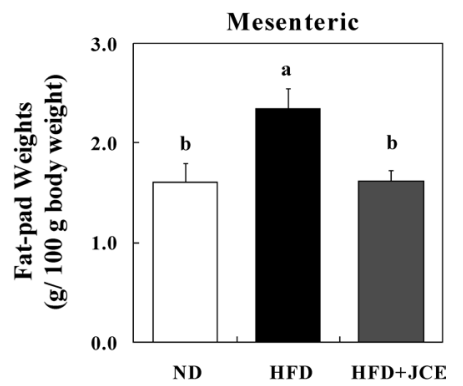

Fig. 1. Effect of JCE on Visceral Fat-pad Weights of Rats Fed Experimental Diets

(A) Epididymal fat-pad weights, (B) perirenal fat-pad weights, (C) mesenteric fat-pad weights, (D) retroperitoneal fat-pad weights, (E) total fat-pad weights. ND, normal diet; HFD, high-fat diet; HFD +JCE, HFD plus $1 \%$ JCE supplemented diet. Values are mean \pm S.E.M., $n=8$. Different alphabets above the bar within a specific visceral fat-pad exhibit a significant difference $(p<0.05)$.

Table 4. Plasma Biochemistries of Rats Fed Experimental Diets

\begin{tabular}{lccr}
\hline \hline & ND & HFD & HFD $+\mathrm{J}$ \\
\hline $\begin{array}{l}\text { Total cholesterol } \\
\quad(\mathrm{mmol} / \mathrm{l})\end{array}$ & $2.13 \pm 0.15^{\mathrm{c}}$ & $3.97 \pm 0.11^{\mathrm{a}}$ & $2.67 \pm 0.13^{\mathrm{b}}$ \\
HDL-cholesterol & $1.29 \pm 0.09^{\mathrm{a}}$ & $0.58 \pm 0.04^{\mathrm{c}}$ & $0.83 \pm 0.09^{\mathrm{b}}$ \\
$\quad(\mathrm{mmol} / \mathrm{l})$ & & & \\
VLDL+LDL-cholesterol & $0.90 \pm 0.16^{\mathrm{c}}$ & $3.42 \pm 0.11^{\mathrm{a}}$ & $1.89 \pm 0.18^{\mathrm{b}}$ \\
$\quad(\mathrm{mmol} / \mathrm{l})$ & & & \\
Atherogenic index $\left.{ }^{a}\right)$ & $0.64 \pm 0.10^{\mathrm{c}}$ & $6.50 \pm 0.77^{\mathrm{a}}$ & $2.64 \pm 0.44^{\mathrm{b}}$ \\
Triglyceride $(\mathrm{mmol} / \mathrm{l})$ & $0.37 \pm 0.03^{\mathrm{b}}$ & $1.11 \pm 0.09^{\mathrm{a}}$ & $0.52 \pm 0.03^{\mathrm{b}}$ \\
Free fatty acid $(\mu \mathrm{Eq} / \mathrm{dl})$ & $52.00 \pm 6.23^{\mathrm{b}}$ & $82.30 \pm 4.82^{\mathrm{a}}$ & $58.50 \pm 1.93^{\mathrm{b}}$ \\
Glucose $(\mathrm{mmol} / \mathrm{l})$ & $8.80 \pm 0.30^{\mathrm{b}}$ & $11.80 \pm 0.71^{\mathrm{a}}$ & $10.90 \pm 0.19^{\mathrm{a}}$ \\
Insulin $(\mathrm{pmol} / \mathrm{l})$ & $101.6 \pm 13.0^{\mathrm{b}}$ & $157.8 \pm 8.8^{\mathrm{a}}$ & $123.0 \pm 11.4^{\mathrm{b}}$ \\
Leptin $(\mathrm{ng} / \mathrm{ml})$ & $3.56 \pm 0.60^{\mathrm{b}}$ & $7.83 \pm 1.03^{\mathrm{a}}$ & $5.10 \pm 0.57^{\mathrm{b}}$ \\
\hline
\end{tabular}

Values are mean \pm S.E.M., $n=8 .{ }^{\text {a,b,c }}$ Means not sharing a common superscript are significantly different $(p<0.05)$. ND, normal diet; HFD, high-fat diet; HFD + JCE, HFD plus $1 \%$ JCE supplemented diet. a) Atherogenic index: (total cholesterol-HDL-cholesterol)/HDL-cholesterol.

plasma HDL-cholesterol concentration was $43 \%$ higher in the HFD+JCE rats than in the HFD rats $(p<0.05)$. Consequently, the JCE supplementation in the HFD significantly reduced the atherogenic index in the rats (by $59 \%, p<0.05$ ). The HFD-induced elevations in the plasma triglyceride and free fatty acid levels of the rats were also substantially reversed when they were fed JCE (53\% and 29\% decreases, respectively, $p<0.05$ ) (Table 4). Similarly, the HFD-induced increases in the plasma insulin and leptin levels of the rats were reduced by dietary supplementation with JCE (22\% and $35 \%$ reductions, respectively, $p<0.05$ ) (Table 4 ).

Expression of Epididymal Adipose Tissue Genes The results from the semi-quantitative RT-PCR analyses of the total RNA prepared from the epididymal adipose tissue of the rats indicate that feeding the rat with the HFD for a pro-

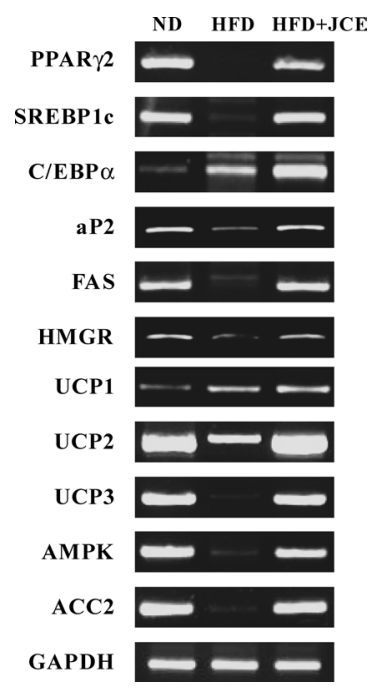

Fig. 2. Effect of JCE on the Transcription of Genes Involved Adipogenesis, Thermogenesis, or Fatty Acid Oxidation in the Epididymal Fat Tissue of Rats

ND, normal diet; HFD, high-fat diet; HFD+JCE, HFD plus $1 \%$ JCE supplemented diet. GAPDH was used as an internal control in semi-quantitative RT-PCR.

longed period apparently down-regulated the expression of PPAR $\gamma 2$, SREBP1c, FAS, UCP2, UCP3, AMPK, and ACC2 genes, whereas it up-regulated the transcription of $\mathrm{C} / \mathrm{EBP} \alpha$ and UCP1 genes (Fig. 2). These HFD-induced down-regulations in the transcription levels of several of the rat's epididymal adipose tissue genes (PPAR $\gamma 2$, SREBP1c, FAS, UCP2, UCP3, AMPK, and ACC2) were dramatically reversed when they were fed with JCE (Fig. 2). The mRNA levels of the adipocyte protein $2(\mathrm{aP} 2)$ and the $\mathrm{HMG}-\mathrm{CoA}$ reductase (HMGR) in the epididymal adipose tissues of the rats basi- 
cally followed the same pattern of diet-induced regulations, as shown in the other genes mentioned above, although the magnitudes of the HFD-induced down-regulation and the JCE-induced up-regulation were smaller than those observed with the seven other genes (Fig. 2). The CEBPa gene, which was upregulated in the rats fed with the HFD unlike in the ND-fed rats, was further increased when they were fed with JCE in their epididymal adipose tissues (Fig. 2).

AMPK and ACC2 Protein Expression and Phosphorylation To determine whether or not the HFD altered the protein levels of the total and phosphorylated forms of the AMPK and ACC2 involved in fatty acid oxidation, Western blot analyses were performed using the whole tissue extract prepared from the epididymal adpose tissues of the rats. The immunoblot results showed that the HFD led to a decrease in the level of both the total- and phospho-AMPK in the epididymal adipose tissues unlike those in the ND rats (Fig. 3). Similarly, both the total- and phospho-ACC2 protein levels of the epididymal adipose tissues of the rats fed with the HFD were down-regulated, than those of the ND rats. Furthermore, the HFD significantly reduced the phosphoAMPK/AMPK ratio (by $74 \%, p<0.05$ ) and the phosphoACC2/ACC2 ratio (by $41 \%, p<0.05$ ) in the epididymal adipose tissues of the rats. These HFD-induced down-regulations in the AMPK and ACC2 protein levels as well as in the ratio of phospho-AMPK/AMPK and the phospho-ACC2/ ACC2 were all significantly reversed in the epididymal adiposes tissue after feeding with JCE (35\% and 29\% increases, respectively, $p<0.05$ ) (Fig. 3).

\section{DISCUSSION}

This study provides the first line of evidence of the antiobesity effect of JCE, along with its working mechanism, in rats with HFD-induced obesity. The dosage of $1 \%$ JCE was chosen from the results of our preliminary study showing a maximum weight reducing activity of JCE in rats when added to the HFD at $0.5 \%, 1 \%$, and $2 \%$ levels (data not shown). The JCE supplementation significantly ameliorated HFD-induced body weight gain, visceral adiposity, dyslipidemia, hyperinsulinemia, and hyperleptinemia in rats, without affecting their food intake. Since adiposity is positively correlated to the plasma leptin concentration in rodents and humans, ${ }^{21)}$ the reduced plasma leptin level found in the HFD+JCE group compared to the HFD group can be attributed to reduced visceral adiposity.

The adipose tissue is a dynamic organ the mass of which changes during lifetime in response to the metabolic requirements of the animal, and thus, plays an important role in energy balance. ${ }^{22)}$ PPAR $\gamma$ is the key regulator of adipogenesis and is required for the maintenance of the differentiated situation. ${ }^{23)}$ A splicing isoform of $\operatorname{PPAR} \gamma, \operatorname{PPAR} \gamma 2$, especially appears to enhance adipocyte proliferation and differentiation from a fibroblast ${ }^{24)}$ and to regulate the expression of adipose-tissue-specific genes, ${ }^{25)}$ such as aP2 $.^{25,26)} \mathrm{C} / \mathrm{EBP} \alpha$ promotes the terminal differentiation of preadipocytes synergistically with PPAR $\gamma 2$. SREBP1c, a pro-adipogenic basic helix-loop-helix transcription factor, induces PPAR $\gamma$ expres$\operatorname{sion}^{27)}$ and regulates the expression of FAS. Differentiated adipocytes store fatty acids in the form of triglycerides in their cytoplasms. This overall lipid synthetic process is called

\section{A. Western blot}

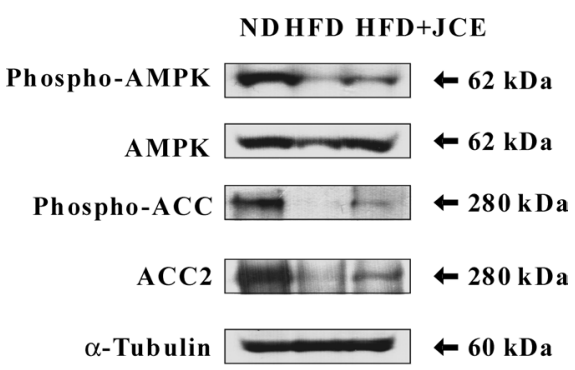

B. phospho-AMPK/AMPK ratio

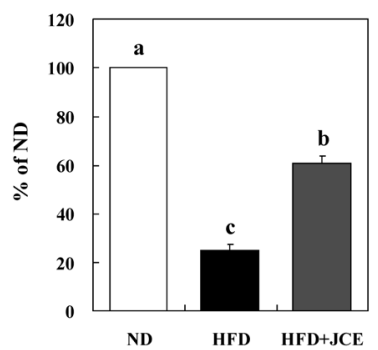

C. phospho-ACC2/ACC2 ratio

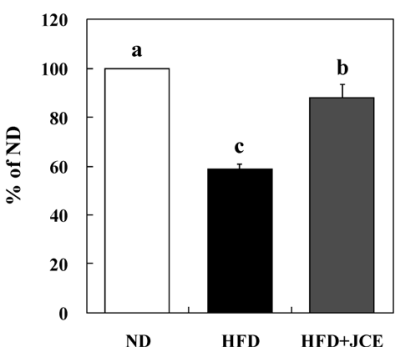

Fig. 3. Effect of JCE on AMPK and ACC2 Protein Expressions in the Epididymal Fat Tissue of Rats

(A) Immunoblots: proteins $(100 \mu \mathrm{g} / \mathrm{lane})$ extracted from the epididymal fat tissue were probed using anti-phospho-AMPK (Thr 172) and anti-AMPK, anti-phosphoACC2 (Ser 79), and anti-ACC2. The blot is a representative experiment of three independent experiments, (B) phospho-AMPK/AMPK protein expression ratio. (C) Phospho-ACC2/ACC2 protein expression ratio. Each bar represents the mean \pm S.E.M. of three independent experiments, $p<0.05$. ND, normal diet; HFD, high-fat diet; HFD+JCE, HFD plus $1 \%$ JCE supplemented diet.

lipogenesis. ${ }^{7)}$

In this study, prolonged HFD consumption did not increase, but rather decreased, the mRNA levels of various genes involved in adipogenesis, such as PPAR $\gamma 2$, aP2, SREBP1c, FAS, and an enzyme that catalyzes the rate-limiting step of cholesterol biosynthesis, HMGR, in the visceral adipose tissue of rats. These results correspond to the previous observation that the expressions of adipogenesis-related genes, including PPAR $\gamma$, SREBP1c, and their target genes (FAS and ACC), decreased in the adipose tissue of a longterm high-fat-diet-fed $\operatorname{dog}^{28)}$ or $o b / o b$ mice $^{29,30)}$ compared with their lean controls. During an early phase of obesity, animals are most likely to be in a state of high adipogenesis and high-energy metabolism. This study examined the long-term effect of an HFD given at a hyper-energetic level. The rats 
had been fully obese for several weeks and their body weights were at a steady state at the end of the excessive energy feeding. Consequently, chronic HFD administration appears to induce an adaptive response in animals that intends to limit further fat deposition. This adaptive response of the genes implicated in adipogenesis was also confirmed in the adipose tissue of obese human subjects who showed reduced mRNA levels of PPAR $\gamma$, SREBP1c and its target genes. ${ }^{31-34)}$ JCE supplementation has restored the HFD-induced downregulation of several genes involved in adipogenesis or cholesterol de novo synthesis in the visceral fat tissues of rats.

UCP2 and UCP3, homologues of UCP1 mostly expressed in the brown adipose tissue (BAT), are expressed in various tissues, such as the BAT, skeletal muscle, white adipose tissue (WAT), liver, kidney, lung, and the immune system. $\mathrm{UCP} 3$, similar to UCP1, is regulated in a manner that suggests a role in thermogenesis and energy balance. ${ }^{35)}$ Interestingly, transgenic over-expression of UCP3 in the skeletal muscles of mice led to decreased adiposity, and reduced plasma insulin, glucose, and cholesterol levels compared to their wild-type littermates. ${ }^{36}$ ) The biological function of UCP2 is unclear, although some reports suggest that this protein may be involved in energy balance and thermogenesis. ${ }^{10)}$ Recent reports that the mRNA level of UCP2 increased in $\mathrm{KK}-\mathrm{A}^{\mathrm{y}}$ mice, an animal model of type 2 diabetes, fed with eicosapentaenoic and docosahexaenoic acids ${ }^{37}$ as well as in human adipocytes in response to anthocyanins ${ }^{38)}$ suggest the possible role of UCP2 as an anti-obesity drug target.

The RT-PCR results clearly indicate that HFD feeding decreases the expression of the UCP2 and UCP3 genes in the visceral adipose tissues of rats. Therefore, reduced thermogenesis, which is associated with the down-regulation of the UCP2 and UCP3 genes in the WAT, may be one of the causes of HFD-induced obesity in rats. These results agree with the previous observation that the UCP 2 and UCP 3 mRNA levels in the skeletal muscles of C57BL/6J mice fed with an HFD were down-regulated, ${ }^{39)}$ but oppose reports that HFD-fed rats exhibited increased the mRNA levels of UCP2 and UCP3 in their skeletal muscles, BATs, and WATs. ${ }^{40,41)}$ Based on the observation that feeding rats with JCE evidently reversed the HFD-induced down-regulation of UCP2 and UCP3 gene expression in the WAT, JCE appears to reduce visceral adiposity, at least in part, by raising uncoupled respiration in the visceral fat tissue. PPAR $\gamma 2$ was investigated as a possible transcription factor involved in white adipose tissue UCP3 regulation, ${ }^{42,43)}$ since a functional peroxisome- proliferatorresponsive element has been identified in the promoter sequence of the UCP3 gene. ${ }^{44)}$ In addition, because aP2 facilitates intracellular mobilization of free fatty acids, ${ }^{45,46)}$ and free fatty acids are known to be natural PPAR $\gamma 2$ agonists, a possible association among PPAR $\gamma 2$, UCP3 and aP2 in the white adipose tissue has been suggested. ${ }^{47)}$ Supporting these reports, the results of this study indicate that the expression levels of PPAR $\gamma 2$, aP2, UCP 2 and UCP 3 genes are positively correlated, and that these four genes are regulated towards the same direction by the experimental diets in the visceral fat tissue. Epididymal mRNA levels of these genes decrease in response to an HFD ( $v s$. an ND) and increase in response to an HFD+JCE ( $v s$. an HFD).

AMPK is a key regulator of intracellular fatty acid metabolism and plays a critical role in response to metabolic stresses such exercise, hypoxia, or long-term starvation. ${ }^{48)}$ Phosphorylated AMPK increases the fatty acid oxidation through phosphorylation (inactivation) of $\mathrm{ACC} 2$, resulting in a decrease in the intracellular malonyl-CoA level and an increase in carnitine palmitoyltransferase 1 (CPT1) activity, the rate-limiting enzyme of mitochondrial fatty acid oxidation. ${ }^{49}$ All these actions of AMPK will tend to decrease the availability of fatty acids in the plasma and metabolic organs such as the adipose tissue, liver, and muscles. Supporting the results of previous studies that reported the AMPK mRNA levels decreased in the muscles and adipose tissues of HFDinduced obese mice, ${ }^{48,50)}$ the mRNA levels of AMPK and ACC 2 also decreased in the visceral adipose tissue of HFDfed rats in this study. The decrease in visceral adiposity caused by JCE in this study appears to have been due, at least in part, to the enhanced $\beta$-oxidation of fatty acid through its function of increasing the AMPK protein expression and phosphorylation and subsequently, of reducing the expression of ACC2 and the phosphorylation of ACC2. Although JCE-induced up-regulations of both protein expression and phosphorylation of AMPK and ACC2 have been measured exclusively in visceral adipose tissue in the present study, other organs such as liver and skeletal muscle should not be ruled out as potential target organs for anti-obesity activity of JCE. We do not know whether the known compounds found in Juniperus chinensis, including flavones, lignans, and diterpenes, are associated with its anti-obesity activity. Further studies are needed to find out the active compound of JCE responsible for the modulation of UCPs and AMPK in the metabolic tissues of obese animals. In conclusion, this study demonstrated, for the first time, that JCE can have a protective effect against HFD-induced obesity in rats through enhanced UCP2 and UCP3 gene expressions, along with increased AMPK and ACC2 protein expression and phosphorylation in the visceral adipose tissue.

Acknowledgements This study was supported by a grant of the Korea Health 21 R\&D Project, Ministry of Health \& Welfare, Republic of Korea (\#A060531), and by the Brain Korea 21 Project, Yonsei University.

\section{REFERENCES}

1) The World Health Report 2002: Reducing Risks, Promoting Healthy Life, World Health Organization, Geneva, 2002.

2) Wellen K. E., Hotamisligil G. S., J. Clin. Invest., 115, 1111-1119 (2005).

3) Tilg H., Moschen A. R., Nat. Rev. Immunol., 6, $772-783$ (2006).

4) Woods S. C., Seeley R. J., Rushing P. A., D'Alessio D., Tso P., J. Nutr., 133, 1081-1087 (2003).

5) Tripathy D., Mohanty P., Dhindsa S., Syed T., Ghanim H., Aljada A., Dandona P., Diabetes, 52, 2882-2887 (2003).

6) Brown M. S., Goldstein J. L., Cell, 89, 331-340 (1997).

7) Weissman C., Crit. Care, 3, R67-75 (1999).

8) Winder W. W., Thomson D. M., Cell Biochem. Biophys., 47, 332-347 (2007).

9) Ledesma A., de Lacoba M. G., Rial E., Genome Biol., 3, reviews 3015.1-3015.9 (2002)

10) Fleury C., Neverova M., Collins S., Raimbault S., Champigny O., Levi-Meyrueis C., Bouillaud F., Seldin M. F., Surwit R. S., Ricquier D., Warden C. H., Nat. Genet., 15, 269-272 (1997).

11) Pittler M. H., Schmidt K., Ernst E., Obes. Rev., 6, 93-111 (2005).

12) Ju J. B., Kim J. S., Choi C. W., Lee H. K., Oh T. K., Kim S. C., J. Ethnopharmacol., 115, 110-115 (2008).

13) Lim J. P., Song Y. C., Kim J. W., Ku C. H., Eun J. S., Leem K. H., Kim 
D. K., Arch. Pharm. Res., 25, 449-452 (2002).

14) Kuo Y. H., Chen W. C., Chem. Pharm. Bull., 42, 1774-1776 (1994).

15) Lee C. K., Fang J. M., Cheng Y. S., Phytochemistry, 39, 391-394 (1995).

16) Ali A. M., Mackeen M. M., Intan-Safinar I., Hamid M., Lajis N. H., el-Sharkawy S. H., Murakoshi M., J. Ethnopharmacol., 53, 165-169 (1996).

17) Miyata M., Itoh K., Tachibana S., J. Wood Sci., 44, 397-400 (1998).

18) Ohashi H., Asai T., Kawai S., Holzforschung, 48, 193-198 (1994).

19) But P. P. H., Kimura T., Gue J. X., Sung C. K., "International Collation of Traditional and Folk Medicine," Vol. 2, ed. by But P. P. H., World Scientific Publishing Co., Pte. Ltd., Singapore, 1997, pp. 16-17.

20) Duke J. A., Ayensu E. S., "Medicinal Plants of China," Reference Publications, Inc., Michigan, 1985.

21) Skurk T., Alberti-Huber C., Herder C., Hauner H., J. Clin. Endocrinol. Metab., 92, 1023-1033 (2007).

22) Harp J. B., Curr. Opin. Lipidol., 15, 303-307 (2004).

23) Tamori Y., Masugi J., Nishino N., Kasuga M., Diabetes, 51, 20452055 (2002).

24) Fajas L., Fruchart J. C., Auwerx J., Curr. Opin. Cell Biol., 10, 165173 (1998)

25) Rousseau V., Becker D. J., Ongemba L. N., Rahier J., Henquin J. C., Brichard S. M., Biochem. J., 321, 451-456 (1997).

26) Gregoire F. M., Smas C. M., Sul H. S., Physiol. Rev., 78, 783-809 (1998).

27) Kim J. B., Spiegelman B. M., Genes Dev., 10, 1096-1107 (1996)

28) Leray V., Gayet C., Martin L., Dumon H., Siliart B., Nguyen P., $J$ Nutr., 134, 2154S-2157S (2004).

29) Soukas A., Cohen P., Socci N. D., Friedman J. M., Genes Dev., 14, 963-980 (2000).

30) Nadler S. T., Stoehr J. P., Schueler K. L., Tanimoto G., Yandell B. S., Attie A. D., Proc. Natl. Acad. Sci. U.S.A., 97, 11371-11376 (2000).

31) Ducluzeau P. H., Perretti N., Laville M., Andreelli F., Vega N., Riou J. P., Vidal H., Diabetes, 50, 1134-1142 (2001).

32) Kolehmainen M., Vidal H., Alhava E., Uusitupa M. I., Obes. Res., 9 , $706-712(2001)$

33) Diraison F., Dusserre E., Vidal H., Sothier M., Beylot M., Am. J. Physiol. Endocrinol. Metab., 282, E46-E51 (2002).
34) Sewter C., Berger D., Considine R. V., Medina G., Rochford J., Ciaraldi T., Henry R., Dohm L., Flier J. S., O'Rahilly S., Vidal-Puig A. J., Diabetes, 51, 1035-1041 (2002).

35) Vidal-Puig A., Solanes G., Grujic D., Flier J. S., Lowell B. B., Biochem. Biophys. Res. Commun., 235, 79-82 (1997).

36) Choi C. S., Fillmore J. J., Kim J. K., Liu Z. X., Kim S., Collier E. F., Kulkarni A., Distefano A., Hwang Y. J., Kahn M., Chen Y., Yu C., Moore I. K., Reznick R. M., Higashimori T., Shulman G. I., J. Clin. Invest., 117, 1995-2003 (2007)

37) Hun C. S., Hasegawa K., Kawabata T., Kato M., Shimokawa T., Kagawa Y., Biochem. Biophys. Res. Commun., 259, 85-90 (1999).

38) Tsuda T., Ueno Y., Yoshikawa T., Kojo H., Osawa T., Biochem. Pharmacol., 71, 1184-1197 (2006).

39) Surwit R. S., Wang S., Petro A. E., Sanchis D., Raimbault S., Ricquier D., Collins S., Proc. Natl. Acad. Sci. U.S.A., 95, 4061-4065 (1998)

40) Matsuda J., Hosoda K., Itoh H., Son C., Doi K., Tanaka T., Fukunaga Y., Inoue G., Nishimura H., Yoshimasa Y., Yamori Y., Nakao K., FEBS Lett., 418, 200-204 (1997).

41) Samec S., Seydoux J., Dulloo A. G., FASEB J., 12, 715-724 (1998).

42) Kelly L. J., Vicario P. P., Thompson G. M., Candelore M. R., Doebber T. W., Ventre J., Wu M. S., Meurer R., Forrest M. J., Conner M. W., Cascieri M. A., Moller D. E., Endocrinology, 139, 4920-4927 (1998).

43) Brun S., Carmona M. C., Mampel T., Vinas O., Giralt M., Iglesias R., Villarroya F., Diabetes, 48, 1217-1222 (1999).

44) Acin A., Rodriguez M., Rique H., Canet E., Boutin J. A., Galizzi J. P., Biochem. Biophys. Res. Commun., 258, 278-283 (1999).

45) Coe N. R., Simpson M. A., Bernlohr D. A., J. Lipid Res., 40, 967972 (1999).

46) Simpson M. A., LiCata V. J., Ribarik Coe N., Bernlohr D. A., Mol. Cell. Biochem., 192, 33-40 (1999).

47) Margareto J., Gomez-Ambrosi J., Marti A., Martinez J. A., Biochem. Biophys. Res. Commun., 283, 6-11 (2001).

48) Liu Y., Wan Q., Guan Q., Gao L., Zhao J., Biochem. Biophys. Res. Commun., 339, 701-707 (2006).

49) Unger R. H., Cell, 117, 145-146 (2004)

50) Wang M. Y., Orci L., Ravazzola M., Unger R. H., Proc. Natl. Acad. Sci. U.S.A., 102, 18011-18016 (2005). 